Bull. Chem. Soc. Ethiop. 2017, 31(1), 63-74.

ISSN 1011-3924

(C) 2017 Chemical Society of Ethiopia and The Authors

Printed in Ethiopia

DOI: http://dx.doi.org/10.4314/bcse.v31i1.6

\title{
FT-IR, NMR SPECTROSCOPIC and QUANTUM MECHANICAL INVESTIGATIONS OF TWO FERROCENE DERIVATIVES
}

\author{
Özgür Alver ${ }^{*}$ and Cemal Parlak ${ }^{2}$ \\ ${ }^{1}$ Department of Physics, Science Faculty, Anadolu University, Eskişehir, 26470, Turkey \\ ${ }^{2}$ Department of Physics, Science Faculty, Ege University, İzmir, 35100, Turkey
}

(Received February 24, 2015; revised February 28, 2017)

\begin{abstract}
New ferrocene derivatives as N-(3-piperidin-1-ylpropyl)ferrocenamide (Fc-3ppa) and N(pyridine-3-ylmethyl)ferrocenamide (Fc-3pica) and structural investigations were carried out with ${ }^{1} \mathrm{H}$, ${ }^{13} \mathrm{C}$, DEPT 45 or 135, HETCOR, COSY NMR and FT-IR spectroscopic techniques. Characterization of Fc-3ppa $\left(\mathrm{FeC}_{19} \mathrm{H}_{26} \mathrm{~N}_{2} \mathrm{O}\right)$ and $\mathrm{Fc}-3$ pica $\left(\mathrm{FeC}_{17} \mathrm{H}_{16} \mathrm{~N}_{2} \mathrm{O}\right)$ was also supported by density functional theory (DFT) used by B3LYP functional and $6-31 \mathrm{G}(\mathrm{d})$ or $6-311++\mathrm{G}(\mathrm{d}, \mathrm{p})$ basis sets. From the combination of all the results, it can be clearly seen that syntheses of Fc-3ppa and Fc-3pica have been successfully achieved. Theoretical values are successfully compared against experimental data and B3LYP method is able to provide satisfactory results for predicting NMR properties and vibrational frequencies of the synthesized ferrocene based systems.
\end{abstract}

KEY WORDS: Ferrocene derivatives, FT-IR, NMR, DFT, B3LYP

\section{INTRODUCTION}

Ferrocene derivatives have widespread applications in chemistry. Because of the redox potential of the ferrocene, different types of organic materials which contain ferrocene moiety were prepared and used in several applications [1-7]. On the other hand, some ligands and complexes including ferrocene moiety were prepared for the inorganic applications [8-11]. Ferrocenoyl amino acids and peptides were prepared using acyl ferrocenes and investigated in detail [12-15].

Fc-3ppa and Fc-3pica compounds are examples of 1,1'-bisferrocene amides. Ferrocene amides have been prepared by amide formation between amines and ferrocenecarboxylic acid derivatives. In these methods, ferrocene carboxylic acid was activated by transforming into; the acid chloride [16] succinimide [17], 1-hydroxybenzotriazole ester in the presence of dicylcohexylcarbodiimide (DCC) [17] or in situ activation of carboxylic acid by $\mathrm{O}-(1 \mathrm{H}-$ benzotriazol-1-yl)-N,N,N',N'-tetramethyluronium hexafluorophosphate (HBTU) or O- $(1 \mathrm{H}-$ benzotriazol-1-yl)-N,N,N',N'-tetramethyluroniumtetrafluoroborate, (TBTU) [18]. Acid fluoride of ferrocene carboxylic acid was prepared for the derivatisation of ferrocenoyl group using cyanuric fluoride [19].

NMR is used extensively as a practical tool for identifying chemical structures. It has been used in chemistry, material science and geochemistry and it provides to get faster and easier structural information. The standard 1D and 2D hetero and homonuclear NMR experiments are enough to afford complete assignment of compounds and very useful to clarify molecular structures [20-22]. For the theoretical NMR investigations, the gauge including atomic orbitals/density functional theory (GIAO/DFT) approach is widely used for various types of compounds [23-31]. The DFT/B3LYP method exhibits good performance on electron affinities, excellent performance on bond energies and reasonably good performance on vibrational frequencies and geometries of inorganic or ionic compounds [32, 33] as well as organic and neutral compounds [34-40].

*Corresponding author. E-mail: ozguralver@anadolu.edu.tr 
In this research two new ferrocene derivatives Fc-3ppa and Fc-3pica were synthesized and characterized by using $1 \mathrm{D}$ or 2D NMR experiments such as ${ }^{1} \mathrm{H},{ }^{13} \mathrm{C}$, DEPT $45-135$, HETCOR and COSY techniques. FT-IR spectra were also reported to identify some important vibrational bands of the compounds. Further, the optimized structural parameters, normal mode frequencies, potential energy distribution (PED) data, ${ }^{1} \mathrm{H}$ and ${ }^{13} \mathrm{C}$ NMR chemical shifts of Fc3ppa and Fc-3pica were examined by B3LYP method with 6-31G(d) and 6-311++G(d,p) basis sets. The results of the theoretical and spectroscopic studies are reported here.

\section{EXPERIMENTAL}

Compounds were prepared according to following method [41]: 3-piperidino-propylamine (1 eq.) or 3-picolylamine (1 eq.) and 1-(ferrocenylcarbonyl)-1H-benzotriazole (1 eq.) were dissolved in freshly distilled chloroform in a round bottom flask. The flask was placed into the single cavity microwave equipment and reflux condenser was connected on flask. The reaction mixture was exposed to $90 \mathrm{~W} \mathrm{MW}$ for $30 \mathrm{~min}$. After reaction was completed, the mixture was extracted with $2 \mathrm{M} \mathrm{NaOH}(3 \times 50 \mathrm{~mL})$. The collected organic layers were dried with magnesium sulfate and solvent was removed with vacuum. Reaction mixture was purified by column chromatography using EtOAc:hexane mixture as eluent to get Fc-3ppa and Fc-3pica in $97 \%$ and in $96 \%$ yields, respectively.

NMR experiments were performed on a Bruker AVANCE 500 spectrometer using $5 \mathrm{~mm}$ BBO probe. The operating frequencies were $500.13 \mathrm{MHz}$ and $125.76 \mathrm{MHz}$ for ${ }^{1} \mathrm{H}$ and ${ }^{13} \mathrm{C}$, respectively. Fc-3ppa $\left(6 \mathrm{mg} \mathrm{mL}^{-1}\right)$ and $\mathrm{Fc}-3$ pica $\left(6 \mathrm{mg} \mathrm{mL}^{-1}\right)$ were dissolved in $\mathrm{CDCl}_{3}$. Fc-3ppa was also dissolved in MeOD. Chemical shifts are reported in ppm relative to TMS for ${ }^{1} \mathrm{H}$ and ${ }^{13} \mathrm{C}$. For ${ }^{13} \mathrm{C}$ NMR spectroscopy, the pulse sequence used a delay (D1) and acquisition time (AQ) of $2.0 \mathrm{~s}$ and $1.3 \mathrm{~s}(1.1 \mathrm{~s})$, respectively, a spectral width of $25252.5 \mathrm{~Hz}(29761.9 \mathrm{~Hz}), 64 \mathrm{~K}$ data points, $90^{\circ}$ pulse $8.3 \mu$ s and 15000 scans. For ${ }^{1} \mathrm{H}$ NMR spectroscopy, the pulse sequence used a delay and acquisition time of $1.0 \mathrm{~s}$ and $5.5 \mathrm{~s}(5.9 \mathrm{~s})$, respectively, a spectral width of $6009.6 \mathrm{~Hz}(5498.5 \mathrm{~Hz}), 64 \mathrm{~K}$ data points, $90^{\circ}$ pulse $14.15 \mu$ s and 256 (32) scans. The numbers given in parentheses belong to $\mathrm{Fc}-3$ pica compound.

DEPT spectra were obtained at $\theta_{\mathrm{z}}=45^{\circ}$ where $\mathrm{CH}, \mathrm{CH}_{2}$ and $\mathrm{CH}_{3}$ appear in the positive phase and $\theta_{\mathrm{z}}=135^{\circ}$ where $\mathrm{CH}, \mathrm{CH}_{3}$ appear in the positive phase and $\mathrm{CH}_{2}$ appears in the negative phase. Two-dimensional HETCOR and COSY techniques were measured using standard micro-programs provided by Bruker. FT-IR spectra were recorded in the region of $400-4000 \mathrm{~cm}^{-1}$ with Perkin-Elmer FT-IR 2000 using $\mathrm{KBr}$ pellet technique at a resolution of 4 $\mathrm{cm}^{-1}$.

The compounds were analyzed for Fe with Perkin Elmer 4300 ICP-OES and for C, H and N with Fisons EA-1108 elemental analyser. Fe metal atom was investigated at $238.204 \mathrm{~nm}$. The results are as following: (found \% / calculated \%) $\mathrm{FeC}_{19} \mathrm{H}_{26} \mathrm{~N}_{2} \mathrm{O}$ (MW: 354.27): $\mathrm{C}(64.38 / 64.41$ ), $\mathrm{H}(7.34 / 7.40), \mathrm{N}(7.82 / 7.91), \mathrm{Fe}(15.64 / 15.76) . \mathrm{FeC}_{17} \mathrm{H}_{16} \mathrm{~N}_{2} \mathrm{O}$ (MW: 320.17): $\mathrm{C}(63.71 / 63.77)$, $\mathrm{H}(4.99 / 5.04), \mathrm{N}(8.67 / 8.75), \mathrm{Fe}(17.33 / 17.44)$.

\section{CALCULATIONS}

All the calculations were performed by Gaussian 03 program [42]. Structures in Figure 1 were first optimized in the gas phase by B3LYP functional using 6-31G(d) basis set. The optimized geometric structures related to minimum on the potential energy surface were provided by solving self-consistent field equation iteratively and optimizations were performed without any molecular restrictions. 


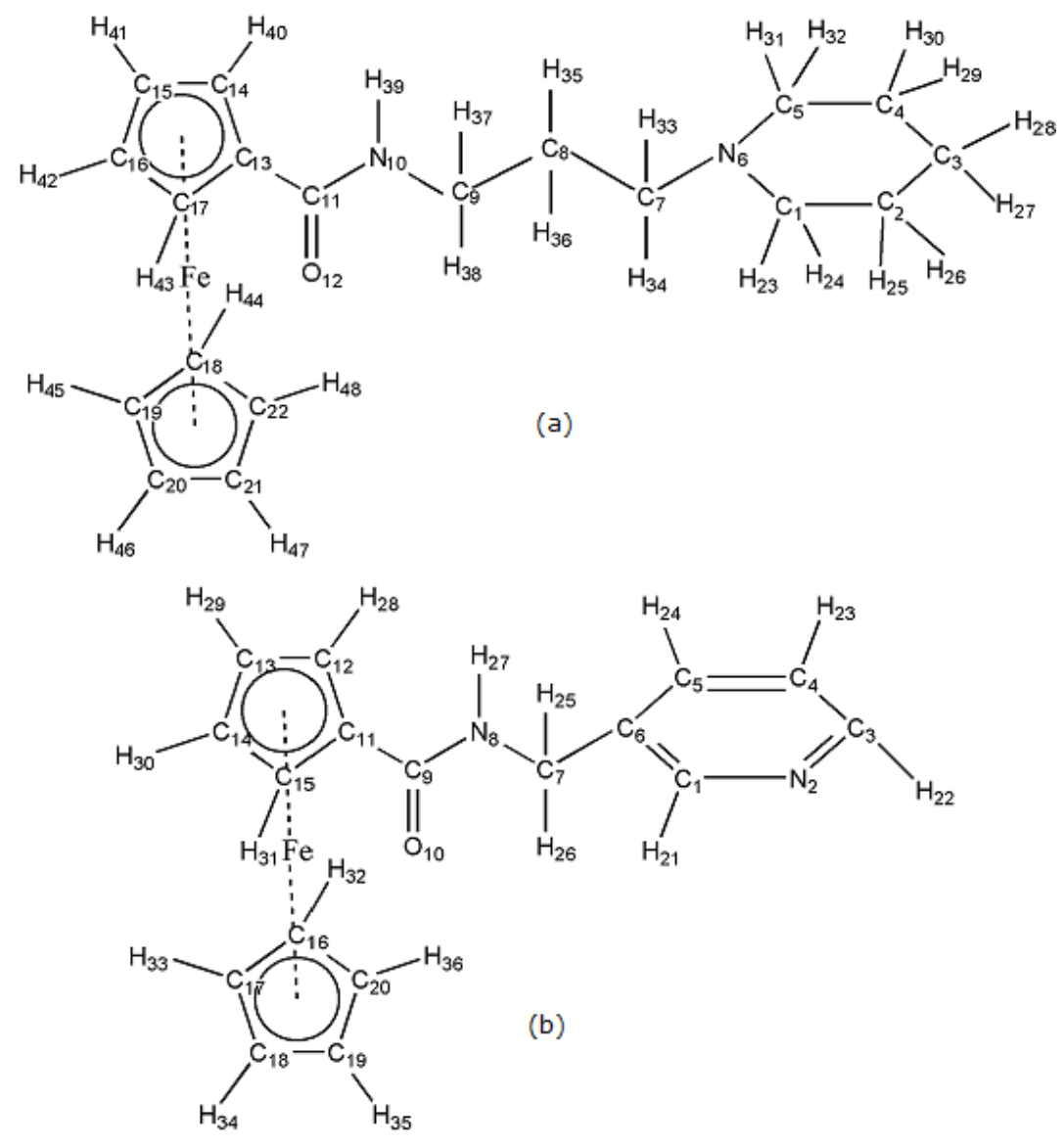

Figure 1. Suggested molecular structures for Fc-3ppa (a) and Fc-3pica (b).

After the optimization, in order to confirm the convergence to minima on the potential surface and to evaluate the zero-point vibrational energies, harmonic vibrational frequencies of the present compounds were determined using analytic second derivatives with the B3LYP/6-31G(d) method and then scaled by 0.955 (above $1800 \mathrm{~cm}^{-1}$ ) and 0.967 (under 1800 $\mathrm{cm}^{-1}$ ) [40, 43]. Additionally, the absence of imaginary frequencies confirmed that the optimized structures are located on a certain minima. PED calculations were carried out by vibrational energy distribution analysis (VEDA 4) program [44].

For the NMR calculations, molecular structures of Fc-3ppa and Fc-3pica were first fully optimized at B3LYP/6-31G(d) level in chloroform $(\varepsilon=4.9)$ using the IEFPCM method [27-30]. After optimization, ${ }^{1} \mathrm{H}$ and ${ }^{13} \mathrm{C}$ NMR chemical shifts $\left(\delta_{\mathrm{H}}\right.$ and $\left.\delta_{\mathrm{C}}\right)$ were calculated using the GIAO method [23-30] in chloroform at the B3LYP/6-311++G(d,p)//6-31G(d) level of theory. Relative chemical shifts were then estimated by using the corresponding TMS shieldings calculated in advance at the same theoretical levels as the reference. Calculated ${ }^{1} \mathrm{H}$ and ${ }^{13} \mathrm{C}$ isotropic chemical shieldings for TMS at the B3LYP/6-311++G $(d, p) / / 6-31 G(d)$ in chloroform using the IEFPCM were $31.87 \mathrm{ppm}$ and $183.76 \mathrm{ppm}$, respectively. Experimental ${ }^{1} \mathrm{H}$ and ${ }^{13} \mathrm{C}$ chemical shieldings for TMS are given as $30.84 \mathrm{ppm}$ and $188.10 \mathrm{ppm}$, respectively [45]. 


\section{RESULTS AND DISCUSSION}

The optimized structures for the synthesized ferrocene based compounds are shown in Figure 1. The optimized geometric parameters of Fc-3ppa such as bond lengths and angles calculated by B3LYP/6-31G(d) are also listed in Table 1. The calculated bond lengths and angles for piperidine, propylamine and ferrocene molecules in Fc-3ppa compound are compared with their previously reported experimental data. The optimized geometric parameters of Fc-3ppa obtained by B3LYP/6-31G(d) method are in good agreement with previously reported data [46-50] as given in Table 1. A brief discussion of the experimental and theoretical NMR and vibrational properties of the title compounds is presented.

Table 1. Optimized geometric parameters of Fc-3ppa calculated by B3LYP/6-31G(d).

\begin{tabular}{|c|c|c|c|c|c|}
\hline Parameters & $\begin{array}{l}{ }^{\mathrm{a}} \text { Experimental } \\
\text { Piperidine }\end{array}$ & $\begin{array}{l}\mathrm{b} \text { Theoretical } \\
\text { Piperidine }\end{array}$ & \begin{tabular}{|l}
${ }^{c}$ Theoretical \\
Propylamine
\end{tabular} & $\begin{array}{l}\text { d,e Experimental } \\
\text { Ferrocene }\end{array}$ & \begin{tabular}{|l|} 
B3LYP \\
6-31G(d)
\end{tabular} \\
\hline \multicolumn{6}{|l|}{ Bond Lengths $(\AA)$} \\
\hline Fe-Cp (subst.) & & & & & $2.049^{\mathrm{f}}$ \\
\hline Fe-Cp (uns.) & & & & 2.054 & $2.053^{\mathrm{f}}$ \\
\hline C13-C14 & & & & & 1.433 \\
\hline $\mathrm{C} 15-\mathrm{C} 16$ & & & & & 1.428 \\
\hline $\mathrm{C} 16-\mathrm{C} 17$ & & & & & 1.425 \\
\hline C13-C11 & & & & & 1.490 \\
\hline C-C (Uns. Cp) & & & & 1.435 & $1.428^{\mathrm{f}}$ \\
\hline $\mathrm{C} 11-\mathrm{O} 12$ & & & & & 1.230 \\
\hline C11-N10 & & & & & 1.370 \\
\hline $\mathrm{C} 14-\mathrm{H} 40$ & & & & & 1.081 \\
\hline $\mathrm{C} 15-\mathrm{H} 41$ & & & & & 1.082 \\
\hline C16-H42 & & & & & 1.082 \\
\hline $\mathrm{C} 17-\mathrm{H} 43$ & & & & & 1.083 \\
\hline C-H (uns. Cp) & & & & 1.073 & $1.082^{f}$ \\
\hline N6-C5 & 1.469 & 1.464 & & & 1.466 \\
\hline N6-C1 & & & & & 1.466 \\
\hline $\mathrm{C} 5-\mathrm{C} 4$ & 1.530 & 1.532 & & & 1.532 \\
\hline $\mathrm{C} 1-\mathrm{C} 2$ & & & & & 1.533 \\
\hline C4-C3 & 1.530 & 1.536 & & & 1.534 \\
\hline N6-C7 & & & & & 1.463 \\
\hline C7-C8 & & & 1.528 & & 1.534 \\
\hline C8-C9 & & & 1.525 & & 1.534 \\
\hline C9-N10 & & & 1.456 & & 1.455 \\
\hline C7-H33 & & & & & 1.109 \\
\hline C7-H34 & & & 1.085 & & 1.096 \\
\hline $\mathrm{C} 8-\mathrm{H} 35$ & & & 1.089 & & 1.098 \\
\hline $\mathrm{C} 8-\mathrm{H} 36$ & & & & & 1.098 \\
\hline C9-H37 & & & 1.086 & & 1.093 \\
\hline C9-H38 & & & 1.093 & & 1.099 \\
\hline N10-H39 & & & 1.002 & & 1.010 \\
\hline$\angle \mathrm{C}-\mathrm{H}$ (piperidine) & 1.098 & 1.100 & & & \\
\hline $\mathrm{C} 1-\mathrm{H} 23$ & & & & & 1.111 \\
\hline C1-H24 & & & & & 1.094 \\
\hline $\mathrm{C} 2-\mathrm{H} 25$ & & & & & 1.098 \\
\hline C2-H26 & & & & & 1.097 \\
\hline C3-H27 & & & & & 1.100 \\
\hline C3-H28 & & & & & 1.097 \\
\hline C4-H29 & & & & & 1.098 \\
\hline
\end{tabular}

Bull. Chem. Soc. Ethiop. 2017, 31(1) 


\begin{tabular}{|l|l|l|l|l|l|}
\hline C4-H30 & & & & & 1.097 \\
\hline C5-H31 & & & & & 1.111 \\
\hline C5-H32 & & & & & 1.097 \\
\hline Bond Angles $\left(^{\circ}\right)$ & & & & & \\
\hline CH-C-H (piperidine) & 110.0 & 107.1 & & & \\
\hline H23-C1-H24 & & & & & 106.8 \\
\hline H25-C2-H26 & & & & & 107.3 \\
\hline H27-C3-H28 & & & & & 106.7 \\
\hline H29-C4-H30 & & & & & 107.3 \\
\hline H31-C5-H32 & & & & & 106.8 \\
\hline H33-C7-H34 & & & & & 106.2 \\
\hline H35-C8-H36 & & & & & 107.0 \\
\hline H37-C9-H38 & & & & & 107.4 \\
\hline C1-N6-C5 & 110.7 & 112.0 & & & 110.8 \\
\hline C1-C2-C3 & 109.6 & 110.6 & & & 110.9 \\
\hline C5-C4-C3 & & & & & 111.0 \\
\hline C4-C3-C2 & 111.1 & 110.7 & & & 110.0 \\
\hline N6-C1-C2 & 110.5 & 109.5 & & & 111.2 \\
\hline N6-C5-C4 & & & & & 111.2 \\
\hline C7-C8-C9 & & & 112.9 & 11.7 \\
\hline C8-C9-N10 & & & 110.7 & & 112.5 \\
\hline
\end{tabular}

${ }^{\mathrm{a}-\mathrm{e}}$ Taken from Ref. 34-38, respectively. ${ }^{\mathrm{f}}$ Average value of C-H and C-C bond lengths. ${ }^{\mathrm{g}}$ Subs.: substituted, Uns.: unsubstituted, Cp: Cyclopentadienyl.

\section{NMR studies}

As can be seen in Figure 1a, Fc-3ppa shows eleven different carbon atoms consistent with structure on the basis of molecular symmetry. Due to electronegative oxygen atom, C11 appears at the highest frequency field region. The most intense singlet appearing at $69.73 \mathrm{ppm}$ arises from unsubstituted ferrocene ring interacting with $\mathrm{Fe}$ atom (Figure 2a). $\mathrm{C} 13$ atom has been overlapped by solvent peak in $\mathrm{CDCl}_{3}$. Therefore, Figure $2 \mathrm{~b}$ is obtained in $\mathrm{MeOD}$ and $\mathrm{C} 13$ has been identified. The peak appearing at $170.00 \mathrm{ppm}$ in ${ }^{13} \mathrm{C}$ NMR spectrum cannot be observed in DEPT 45 and 135 spectra (Figure 2d). Henceforth, it can be concluded that it is C11. In DEPT 135 spectrum, $\mathrm{CH}_{2}$ appears in the negative phase. In DEPT 45 spectrum, $\mathrm{CH}$ and $\mathrm{CH}_{2}$ appear in positive phase. For that reason, ferrocene protons can easly be differentiated from other protons in Fc-3ppa. ${ }^{1} \mathrm{H}$ NMR spectrum is given in Figure 2f. Ferromagnetic Fe atoms effect the relaxation mechanism of the compounds. Therefore, we observe broadened proton peaks. The broad signals are observed in the spectrum may also indicate paramagnetic impurities. The peak which appears at $7.48 \mathrm{ppm}$ belongs to the (-NH-) amide group, so it doesn't have any interaction in HETCOR spectrum (Figure 3a). The correlations between $\mathrm{C} 1-\mathrm{H} 23,24, \mathrm{C} 5-$ $\mathrm{H} 31,32$, C2-H25,26, C4-H29,30, C3-H27,28, C7-H33,34, C8-H35,36, C9-H37,38, C14-H40, C15-H41, C16-H42, C17-H43 and $\mathrm{CH}$ (unsubstituted Cp ring) are also clearly observed in HETCOR spectrum. From COSY spectrum (Figure 3c), it is clear that there is a correlation between $\mathrm{H} 35,36-\mathrm{H} 33,34, \mathrm{H} 35,36-\mathrm{H} 37,38$ and H37,38-H39.

As can be seen in Figure 1b, Fc-3pica molecule contains eleven different carbon atoms consistent with the structure on the basis of molecular symmetry. Due to electronegative oxygen atom, C9 appears at the highest frequency field region. The most intense singlet appearing at $69.75 \mathrm{ppm}$ arises from unsubstituted ferrocene ring interacting with $\mathrm{Fe}$ atom (Figure 2c). When integration values of ${ }^{1} \mathrm{H}$ NMR spectrum are investigated from Figure $2 \mathrm{~g}$, it can be seen that total integration values are in compliance with the total number of protons in Fc-3pica. Ferromagnetic atoms effect the relaxation mechanism of the compounds. Therefore, we observe broadened proton peaks. The peaks those appear at $170.63 \mathrm{ppm}, 134.59 \mathrm{ppm}$ and $75.57 \mathrm{ppm}$ in 
${ }^{13} \mathrm{C}$ NMR spectrum can not be observed in DEPT 135 spectrum (Figure 2e). Henceforth, it can be concluded that they belong to carbon atoms C9, C6 and C11, respectively. In DEPT 135 spectrum, $\mathrm{CH}_{2}$ appears in the negative phase. Therefore, the peak which is located at $41.12 \mathrm{ppm}$ can be assigned to $\mathrm{C} 7$ atom. It is clear from HETCOR spectrum (Figure $3 \mathrm{~b}$ ) that there is no $\mathrm{H}$ atom bonded to C9, C6 and C11 as expected. Thus, HETCOR spectrum is in agreement with the DEPT 135 spectrum. The peak which appears at $6.12 \mathrm{ppm}$ belongs to the (-NH-) amide group, therefore, it doesn't have any interaction in the HETCOR spectrum. The correlations between $\mathrm{C} 1-\mathrm{H} 21, \mathrm{C} 3-\mathrm{H} 22$, C4-H23, C5-H24, C7-H25,26, C12-H28, C15-H31, C13-H29, C14-H30 and $\mathrm{C}-\mathrm{H}$ (ferrocene ring) are also clearly observed in HETCOR spectrum. From the COSY NMR spectrum (Figure 3d), it is clear that there is a correlation between $\mathrm{H} 23-\mathrm{H} 22,24, \mathrm{H} 27-\mathrm{H} 25,26$ and between the substituted ferrocene ring's hydrogen atoms.

Experimental and calculated ${ }^{13} \mathrm{C}$ and ${ }^{1} \mathrm{H}$ NMR chemical shifts of Fc-3ppa and Fc-3pica are given in Table 2. The largest difference between experimental and computed chemical shifts for proton / carbon of Fc-3ppa and Fc-3pica is $0.58 \mathrm{ppm} / 3.39 \mathrm{ppm}$ and $0.72 \mathrm{ppm} / 2.98 \mathrm{ppm}$, respectively. In order to compare experimental and calculated chemical shifts, the correlation graphics have been performed and the correlation values for proton and carbon chemical shifts of Fc-3ppa and Fc-3pica are found to be 0.99491 / 0.99959 and 0.98985 / 0.99975 for B3LYP/6$311++\mathrm{G}(\mathrm{d}, \mathrm{p}) / / 6-31 \mathrm{G}(\mathrm{d})$ model, respectively.
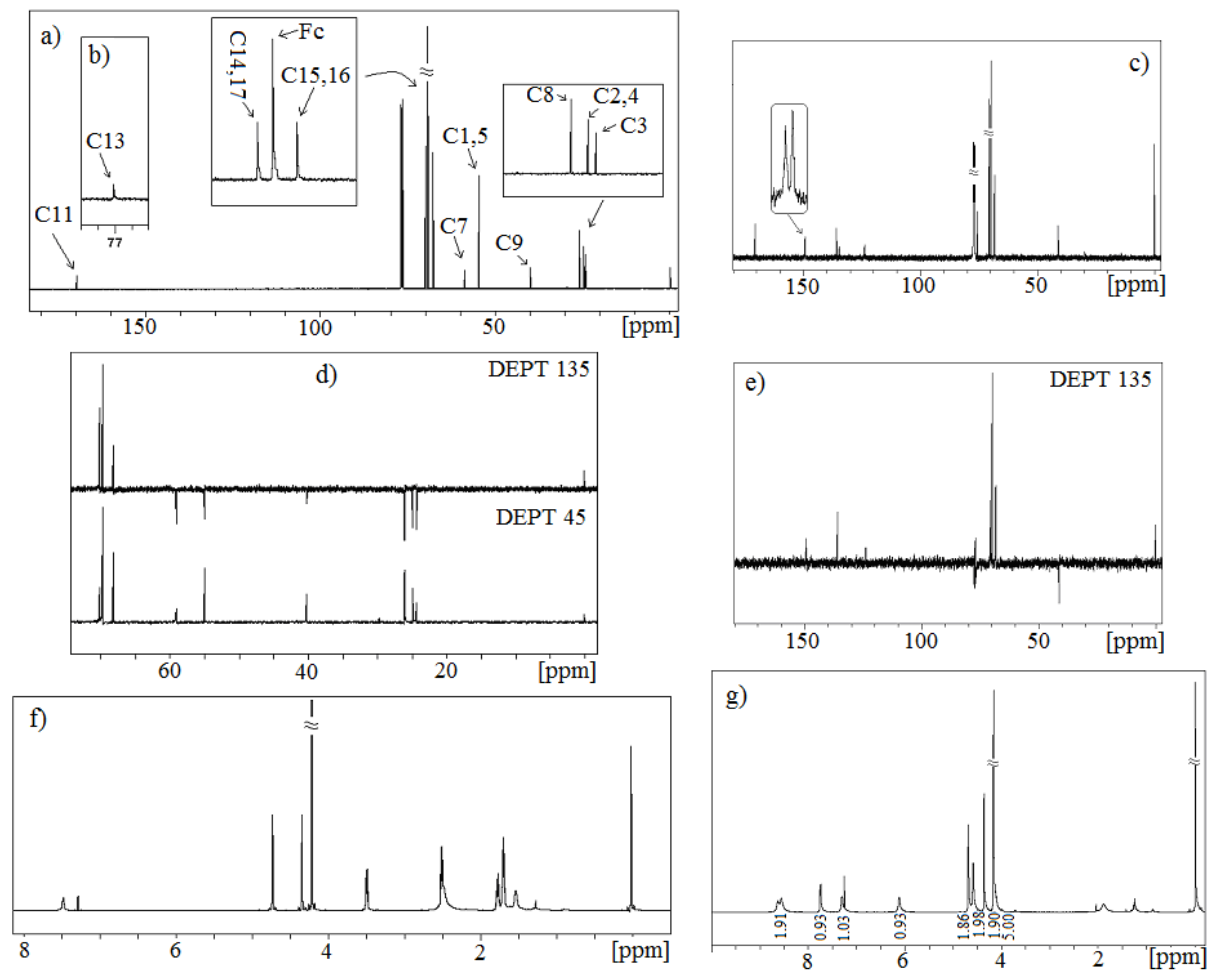

Figure $2 .{ }^{13} \mathrm{C}(\mathrm{a}, \mathrm{b}, \mathrm{c})$, DEPT $(\mathrm{d}, \mathrm{e}),{ }^{1} \mathrm{H}(\mathrm{f}, \mathrm{g})$ NMR spectra of Fc-3ppa (a, b, d, f) and Fc-3pica (c, $\mathrm{e}, \mathrm{g})$. 


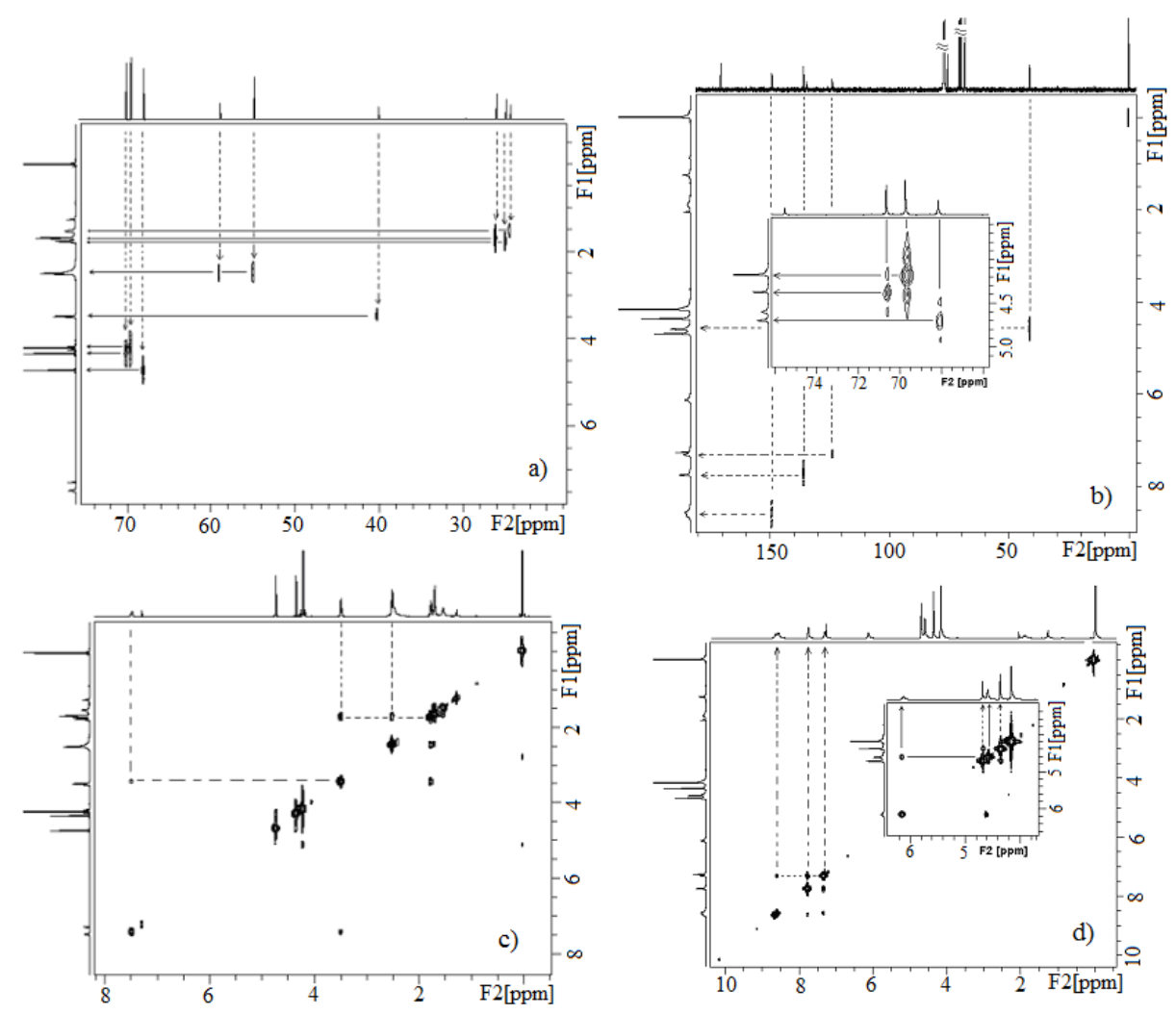

Figure 3. HETCOR (a, b) and COSY (c, d) NMR spectra of Fc-3ppa (a, c) and Fc-3pica (b, d).

\section{FT-IR studies}

Some important measured and calculated vibrational frequencies for the present compounds along with corresponding vibrational assignments and PED data are given in Table 3 and their experimental vibrational spectra are shown in Figure 4. Fc-3ppa and Fc-3pica compounds consist of 49 and 37 atoms, so they have 141 and 105 normal vibrational modes and they belong to the point group $\mathrm{C}_{1}$ with only identity (E) symmetry element or operation. It is difficult to determine these complexes's vibrational assignments in the observed spectrum due to its low symmetry. Therefore, the assignments of vibrational modes of these compounds have been provided by VEDA 4 in Table 3.

It is clearly observed in Figure 4 that the NH stretching band which appears as a strong broad at $3347 \mathrm{~cm}^{-1}\left(3268 \mathrm{~cm}^{-1}\right)$ is attributed to amide group. The $\mathrm{CH}$ stretching bands at between 3104-3070 $\mathrm{cm}^{-1}\left(3160-3042 \mathrm{~cm}^{-1}\right)$ result from ferrocene group while $\mathrm{CH}_{2}$ antisymmetric and symmetric stretching bands having various intensities at 2850 and $2926 \mathrm{~cm}^{-1}$ (2937 and $2969 \mathrm{~cm}^{-1}$ ) arise from $\mathrm{CH}_{2}$ located on the piperidine ring (pyridine ring) and propylamine chain (methylamine chain). The very strong amide $\mathrm{CO}$ stretching band appears at $1630 \mathrm{~cm}^{-1}\left(1639 \mathrm{~cm}^{-1}\right)$. The representations given in parentheses refer to $\mathrm{Fc}-3$ pica compound. Other important bands observed in the spectrum of Fc-3ppa are as following: $1534 \mathrm{~cm}^{-1}$ (vs, $\mathrm{CNH}$ combination $\left[\mathrm{v}_{\mathrm{CN}}+\delta_{\mathrm{NH}}\right]$, amide), $1469 \mathrm{~cm}^{-1}$ and $1450 \mathrm{~cm}^{-1}$ (w/s, $\mathrm{CH}_{2}$ deformation), 1432 
$\mathrm{cm}^{-1}$ (s, $\delta_{\mathrm{NH}}$, amide), $1372 \mathrm{~cm}^{-1}$ (m, $v_{\mathrm{CN}}$, amide), $1345 \mathrm{~cm}^{-1}$ (w, $\mathrm{CH}_{2}$ twisting), $1289 \mathrm{~cm}^{-1}$ (s, $\mathrm{CNH}$ combination $\left[v_{\mathrm{CN}}+\delta_{\mathrm{NH}}\right]$, amide) and $772 \mathrm{~cm}^{-1}$ (m, NH deformation). Other important bands observed in the spectrum of Fc-3pica are as following: $1588 \mathrm{~cm}^{-1}$ (s, $v_{\mathrm{CC}}$, pyridine), $1530 \mathrm{~cm}^{-1}$ (vs, CNH combination $\left[v_{\mathrm{CN}}+\delta_{\mathrm{NH}}\right]$, amide), $1474 \mathrm{~cm}^{-1}$ (w, $\mathrm{CH}_{2}$ deformation), $1425 \mathrm{~cm}^{-1}$ (m, $\delta_{\mathrm{NH}}$, amide), $1375 \mathrm{~cm}^{-1}$ ( $\mathrm{m}, v_{\mathrm{CN}}$, amide), $1343 \mathrm{~cm}^{-1}$ (w, CH deformation, pyridine), $1296 \mathrm{~cm}^{-1}$ (vs, $\mathrm{CNH}$ combination $\left[\mathrm{v}_{\mathrm{CN}}+\delta_{\mathrm{NH}}\right]$, amide) and $757 \mathrm{~cm}^{-1}$ (m, NH deformation).

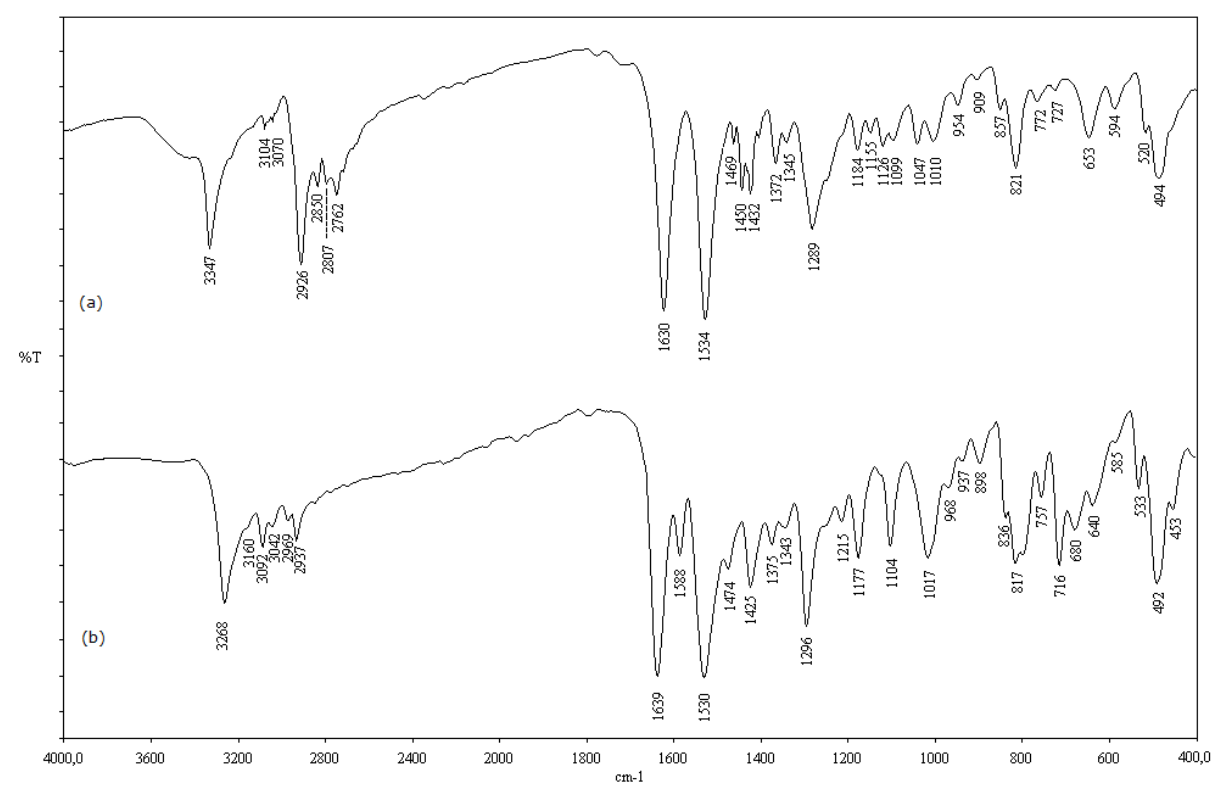

Figure 4.FT-IR spectra of Fc-3ppa (a) and Fc-3pica (b).

As it can be seen from Table 3, in general, there is a good agreement between the experimental and theoretical vibrational frequencies. The largest difference between the given experimental and calculated frequencies is $14 \mathrm{~cm}^{-1}$ for $\mathrm{Fc}-3 \mathrm{ppa}$ and $15 \mathrm{~cm}^{-1}$ for $\mathrm{Fc}-3$ pica. The differences between the calculated and experimental values for the some vibrational modes are often attributed to the neglected anharmonicity and incomplete inclusion of electronic correlation effects. In order to compare the given frequencies, we have found the correlation graphics based on the calculations and experimental IR data. The correlation values between the given experimental and calculated frequencies are found to be 0.99996 for Fc-3ppa and 0.99995 for Fc-3pica as seen in Figure 5. 

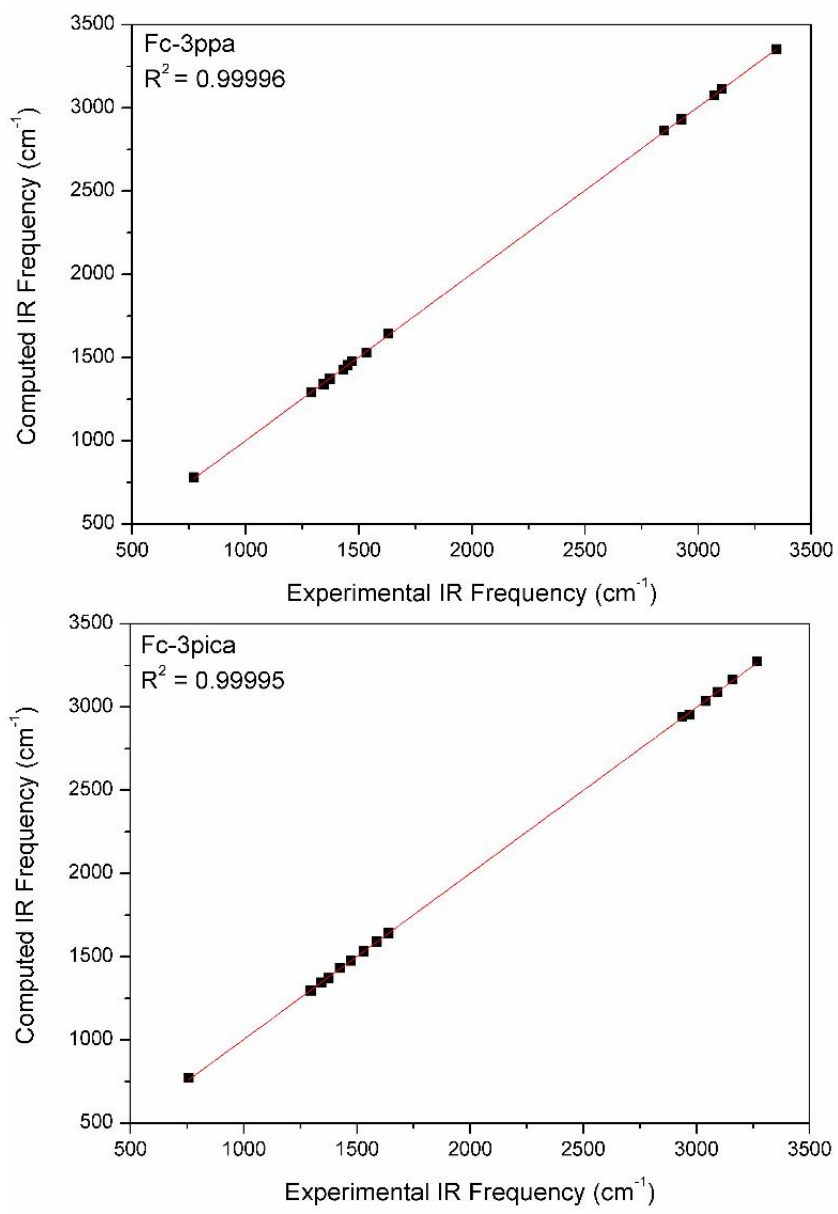

Figure 5. Plot of the calculated vs the experimental vibrational wavenumbers of Fc-3ppa and Fc3pica.

\section{CONCLUSIONS}

We have carried out a comprehensive spectroscopic investigation for Fc-3ppa and Fc-3pica by means of NMR, FT-IR, ICP-OES and elemental analyses. According to the spectroscopic results, it can be concluded that synthesis of these compounds have been accomplished successfully. The theoretical researches of the present compounds are also performed using quantum mechanical calculations. The calculated chemical shifts and vibrational frequencies are in compliance with the experimentally reported results. All results indicate that B3LYP method is reliable and it can be used to understand the structural parameters, NMR and vibrational spectra of ferrocene based compounds. The findings of this research can be useful for better understanding possible future applications of ferrocene based systems. 


\section{ACKNOWLEDGEMENTS}

We are deeply grateful to Michal Jamróz, Deniz Hür and Kaido Tämm for their valuable contributions during this study.

\section{REFERENCES}

1. Baldoli, C.; Oldani, C.; Licandro, E.; Ramani, P.; Valerio, A.; Ferruti, P.; Falciola, L. Mussini, P. Ferrocene derivatives supported on poly(N-vinylpyrrolidin-2-one) (PVP): Synthesis of new water-soluble electrochemically active probes for biomolecules. $J$. Organometal. Chem. 2007, 692, 1363-1371.

2. Jios, J.L.; Kirin, S.I.; Buceta, N.N.; Weyhermuller, T.; Della Ve'dova, C.O.; Metzler-Nolte, N.J. Synthesis and structural characterization of metallated bioconjugates: C-terminal labeling of amino acids with aminoferrocene. Organometal. Chem. 2007, 692, 4209-4214.

3. Li, C.; Medina, J.C.; Maguire, G.E.M.; Abel, E.; Atwood, J.L.; Gokel, G.W. Neutral molecule receptor systems using ferrocene's "atomic ball bearing" character as the flexible element. J. Am. Chem. Soc. 1997, 119, 1609-1618.

4. Beer, P.D.; Szemes, F.; Balzani, V.; Sala, C.M.; Drew, M.G.B.; Dent, S.W.; Maestri, M. Anion selective recognition and sensing by novel macrocyclictransition metal receptor systems. ${ }^{1} \mathrm{H}$ NMR, electrochemical, and photophysical investigations. J. Am. Chem. Soc. 1997, 119, 11864-11875.

5. Tao, G.; Katz, E.; Willner, I. Enantioselective bioelectrocatalyzed oxidation of glucose by glucose oxidase at chiral-monolayer-electrodes. J. Chem. Soc. Chem. Commun. 1997, 20732074.

6. Zhang, L.; Godinez, L.A.; Lu, T.; Gokel, G.W.; Kaifer, A.E. Molecular recognition at an interface: Binding of monolayer-anchored ferrocenyl groups by an amphiphilic calixarene host. Angew. Chem. Int. Ed. Engl. 1995, 34, 235-237.

7. Wang, K.; Munoz, S.; Zhang, L.; Castro, R.; Kaifer, A.E.; Gokel, G.W. Organometallic amphiphiles: Oxidized ferrocene as headgroup for redox-switched bilayer and monolayer membranes. J. Am. Chem. Soc. 1996, 118, 6707-6715.

8. Mourgues, S.; Serra, D.; Lamy, F.; Vincendeau, S.; Daran, J-C.J.-C.; Manoury, E.; Gouygou, M. Chiral [(dialkylamino)methyl](phospholyl)ferrocene ligands as a new class of 1,2-disubstituted ferrocene ligands. Eur. J. Inorg. Chem. 2003, 2820-2826.

9. Cotton, H.K.; Huerta, F.F.; Backvall, J-E. Highly selective negishi cross-coupling reaction of a zinc-metallatedferrocenyl $p$-tolyl sulfoxide: New chiral ferrocene-based quinone ligands. Eur. J. Org. Chem. 2003, 68, 2756-2763.

10. Hou, H.; Li, G.; Song, Y.; Fan, Y.; Zhu, Y.; Zhu, L. Synthesis crystal structures and third order nonlinear optical properties of two novel ferrocenyl Schiff base complexes. Eur. J. Inorg. Chem. 2003, 2325-2332.

11. Auzias, M.; Therrien, B.; Suss-Fink, G. 1,1'-Ferrocene dicarboxylic acid pyridine-4-yl ester: A new bidentate ligand in arene ruthenium chemistry. Inorg. Chem. Commun. 2007, 10, 1239-1243.

12. Kirin, S.I.; Schatzschneider, U. Hatten, X. de; Weyhermuller, T.; Metzler-Nolte, N. 1, n' Disubstitutedferrocenoyl amino acids and dipeptides: Conformational analysis by $\mathrm{CD}$ spectroscopy, X-ray crystallography, and DFT calculations. J. Organometal. Chem. 2006, 691, 3451-3457.

13. Appoh, F.E.; Sutherland, T.C.; Kraatz, H-B. Changes in the hydrogen bonding pattern in ferrocene peptides. J. Organometal. Chem. 2004, 689, 4669-4677.

14. Orlowski, G.A.; Chowdhury, S.; Kraatz, H-B. The effect of alkali metal ions on the electrochemical behavior of ferrocene-peptide conjugates immobilized on gold surfaces. Electrochim. Acta 2007, 53, 2034-2039. 
15. Hatten, X. de; Weyhermuller, T.; Metzler-Nolte, N. Ferrocenoyl peptides with sulfurcontaining side chains: synthesis, solid state and solution structures. J. Organometal. Chem. 2004, 689, 4856-4867.

16. Herrick, R.S.; Jarret, R.M.; Curran, T.P.; Dragoli, D.R.; Flaherty, M.B.; Lindyberg, S.E.; Slate, R.A.; Thornton, L.C. Ordered conformations in bis(amino acid) derivatives of 1,1'ferrocenedicarboxylic acid. Tetrahedron Lett. 1996, 37, 5289-5292.

17. Kraatz, H-B.H.-B.; Lusztyk, J.; Enright, G.D. Ferrocenoyl amino acids: A synthetic and structural study. Inorg. Chem. 1997, 36, 2400-2405.

18. van Staveren, D.R.; Weyhermuller, T.; Metzler-Nolte, N. Organometallic $\beta$-turn mimetics. A structural and spectroscopic study of inter-strand hydrogen bonding in ferrocene and cobaltocenium conjugates of amino acids and dipeptides. Dalton Trans. 2003, 210-220.

19. Galow, T.H.; Rodrigo, J.; Cleary, K.; Cooke, G.; Rotello, V.M. Fluorocarbonylferrocene: A versatile intermediate for ferrocene esters and amides. J. Org. Chem. 1999, 64, 3745-3746.

20. Contreras, R.H.; Peralta, J.E. Angular dependence of spin-spin coupling constants. Prog. Nucl. Magn. Reson. Spectrosc. 2000, 37, 321-425.

21. Beraldo, H.; Nacif, W.F.; West, D.X. Spectral studies of semicarbazones derived from 3and 4-formylpyridine and 3- and 4-acetylpyridine: Crystal and molecular structure of 3formylpyridine semicarbazone. Spectrochim. Acta A 2001, 57, 1847-1854.

22. Abdel-Shafi, A.A. Effect of $\beta$-cyclodextrin on the excited state proton transfer in 1naphthol-2-sulfonate. Spectrochim. Acta A 2001, 57, 1819-1828.

23. Alver, Ö.; Parlak, C.; Bilge, M. Experimental and theoretical NMR study of 4-(1pyrrolidinyl)piperidine. Bull. Chem. Soc. Ethiop. 2011, 25, 437-442.

24. Alver, Ö.; Parlak, C.; Şenyel, M. ${ }^{1} \mathrm{H},{ }^{13} \mathrm{C}$ NMR and ${ }^{\mathrm{n}} \mathrm{JCH}$ coupling constants investigation of 4-phenylpyridine: A combined experimental and theoretical study. Phys. Lett. A 2007, 371, 300-306.

25. Parlak, C.; Alver, Ö.; Şenyel, M. Experimental and theoretical NMR study of 4-(3cyclohexen-1-yl)pyridine. Spectrochim. Acta A 2008, 69, 1252-1256.

26. Şenyel, M.; Alver, Ö.; Parlak, C. ${ }^{1} \mathrm{H},{ }^{13} \mathrm{C},{ }^{15} \mathrm{~N}$ NMR and ${ }^{n} \mathrm{~J}_{(\mathrm{C}, \mathrm{H})}$ coupling constants investigation of 3-piperidino-propylamine: A combined experimental and theoretical study. Spectrochim. Acta A 2008, 71, 830-834.

27. Barone, G.; Paloma, L.G.; Duca, D.; Silvestri, A.; Riccio, R.; Bifulco, G. Structure validation of natural products by quantum-mechanical GIAO calculations of ${ }^{13} \mathrm{C}$ NMR chemical shifts. Chem. Eur. J. 2002, 8, 3233-3239.

28. Bagno, A.; Rastrelli, F.; Saielli, G. Toward the complete prediction of the ${ }^{1} \mathrm{H}$ and ${ }^{13} \mathrm{C}$ NMR spectra of complex organic molecules by DFT methods: Application to natural substances. Chem. Eur. J. 2006, 12, 5514-5525.

29. Helgaker, T.; Jaszunski, M.; Ruud, K. Ab initio methods for the calculation of NMR shielding and indirect spin-spin coupling constants. Chem. Rev. 1999, 99, 293-352.

30. Bagno, A.; Rastrelli, F.; Saielli, G. Predicting ${ }^{13} \mathrm{C}$ NMR Spectra by DFT Calculations. J. Phys. Chem. A 2003, 107, 9964-9973.

31. Bifulco, G.; Bassarello, C.; Riccio, R.; Paloma, L.G. Quantum mechanical calculations of NMR J coupling values in the determination of relative configuration in organic compounds. Org. Lett. 2004, 6, 1025-1028.

32. Check, C.E.; Faust, T.O.; Bailey, J.M.; Wright, B.J.; Gilbert, T.M.; Sunderlin, L.S. Addition of polarization and diffuse functions to the LANL2DZ basis set for p-block elements. $J$. Phys. Chem. A 2001, 105, 8111-8116.

33. Bytheway, I.; Wong, M.W. The prediction of vibrational frequencies of inorganic molecules using density-functional theory. Chem. Phys. Lett. 1998, 282, 219-226.

34. Becke, A.D. Density-functional thermochemistry. III. The role of exact exchange. J. Chem. Phys. 1993, 98, 5648-5652. 
35. Scott, A.P.; Radom, L. Harmonic vibrational frequencies: An evaluation of Hartree-Fock, Møller-Plesset, quadratic configuration interaction, density functional theory, and semiempirical scale factors. J. Phys. Chem. 1996, 100, 16502-16513.

36. Durig, J.R.; Zhu, X.; Guirgis, G.A. Infrared and Raman spectra, conformational stability, ab initio calculations and vibrational assignment of 2-fluorobutane. Spectrochim. Acta A 2004, 60, 829-841.

37. Durig, J.R.; Ganguly, A.; El Defrawy, A.M.; Gounev, T.K.; Guirgis, G.A. Conformational stability of cyclobutanol from temperature dependent infrared spectra of xenon solutions, structural parameters, ab initio calculations and vibrational assignment. Spectrochim. Acta A 2008, 71, 1379-1389.

38. Parlak, C. Theoretical and experimental vibrational spectroscopic study of 4-(1pyrrolidinyl)piperidine. J. Mol. Struct. 2010, 966, 1-7.

39. Alver, Ö.; Parlak, C. DFT, FT-Raman, FT-IR, liquid and solid state NMR studies of 2,6dimethoxyphenylboronic acid. Vib. Spectrosc. 2010, 54, 1-9.

40. Alver, Ö.; Parlak, C. Vibrational spectroscopic investigation and conformational analysis of 1-pentylamine: A comparative density functional study. J. Theor. Comput. Chem. 2010, 9, 667-685.

41. Ekti, S.F.; Hür, D. Microwave assisted synthesis of ferrocene amides. Inorg. Chem. Commun. 2008, 11, 1027-1029.

42. Frisch, M.J. Trucks, G.W.; Schlegel, H.B.; Scuseria, G.E.; Robb, M.A.; Cheeseman, J.R.; Montgomery, Jr., J.A.; Vreven, T.; Kudin, K.N.; Burant, J.C.; Millam, J.M.; Iyengar, S.S.; Tomasi, J.; Barone, V.; Mennucci, B.; Cossi, M.; Scalmani, G.; Rega, N.; Petersson, G.A.; Nakatsuji, H.; Hada, M.; Ehara, M.; Toyota, K.; Fukuda, R.; Hasegawa, J.; Ishida, M.; Nakajima, T.; Honda, Y.; Kitao, O.; Nakai, H.; Klene, M.; Li, X.; Knox, J.E.; Hratchian, H. P.; Cross, J.B.; Bakken, V.; Adamo, C.; Jaramillo, J.; Gomperts, R.; Stratmann, R.E.; Yazyev, O.; Austin, A.J.; Cammi, R.; Pomelli, C.; Ochterski, J.W.; Ayala, P.Y.; Morokuma, K.; Voth, G.A.; Salvador, P.; Dannenberg, J.J.; Zakrzewski, V.G.; Dapprich, S.; Daniels, A.D.; Strain, M.C.; Farkas, O.; Malick, D.K.; Rabuck, A.D.; Raghavachari, K.; Foresman, J.B.; Ortiz, J.V.; Cui, Q.; Baboul, A.G.; Clifford, S.; Cioslowski, J.; Stefanov, B.B.; Liu, G.; Liashenko, A.; Piskorz, P.; Komaromi, I.; Martin, R.L.; Fox, D.J.; Keith, T.; Al-Laham, M.A.; Peng, C.Y.; Nanayakkara, A.; Challacombe, M.; Gill, P.M.W.; Johnson, B.; Chen, W.; Wong, M.W.; Gonzalez, C.; and Pople, J.A. Gaussian 03 Revision C.02, Gaussian Inc.: Pittsburgh PA; 2003.

43. Alver, Ö.; Parlak, C. Vibrational spectroscopic investigation and conformational analysis of 1-cyclohexylpiperazine. J. Mol. Struct. 2010, 975, 85-92.

44. Jamróz, M.H. Vibrational Energy Distribution Analysis, VEDA 4 program: Warsaw; 2004.

45. Cheeseman, J.R.; Trucks, G.W.; Keith, T.A.; Frisch, M.J. A comparison of models for calculating nuclear magnetic resonance shielding tensors. J. Chem. Phys. 1996, 104, $5497-$ 5509.

46. Vedal, D.; Ellestad, O.H.; Klaboe, P.; Hagen, G. The vibrational spectra of piperidine and morpholine and their N-deuterated analogs. Spectrochim. Acta A 1976, 32, 877-890.

47. Güllüoğlu, M.T.; Erdoğdu, Y.; Yurdakul, Ş. Molecular structure and vibrational spectra of piperidine and 4-methylpiperidine by density functional theory and ab initio Hartree-Fock calculations. J. Mol. Struct. 2007, 834-836, 540-547.

48. Durig, J.R.; Beshir, W.B.; Godbey, S.E.; Hizer, T.J. Raman and infrared spectra, conformational stability and ab initio calculations for n-propylamine. J. Raman Spectrosc. 1989, 20, 311-333.

49. Haaland, A.; Nilsson, J. The determination of barriers to internal rotation by means of electron diffraction. Ferrocene and ruthenocene. Acta Chem. Scand. 1968, 22, 2653-2670.

50. Brock, C.P.; Fu, Y. Rigid-body disorder models for the high-temperature phase of ferrocene. Acta Crystallogr. B 1997, 53, 928-938. 